Review

\title{
Hazard Analysis Critical Control Point (HACCP) sebagai Jaminan Keamanan Produk Sarang Burung Walet Tujuan Ekspor ke Tiongkok
}

\section{A Review on Food Safety Animal Origin Implementation by Hazard Analysis Critical Control Point (HACCP) in Swiflet Birdnest Processing Unit}

\author{
Rizal Eko Kurniawan', Chaerul Basri², Hadri Latif ${ }^{2}$ \\ ${ }^{1}$ Mahasiswa Pascasarjana Kesehatan Masyarakat Veteriner, Fakultas Kedokteran Hewan, Institut Pertanian Bogor \\ ${ }^{2}$ Dosen Divisi Kesehatan Masyarakat Veteriner dan Epidemiologi, Ilmu Penyakit Hewan dan Kesehatan Masyarakat \\ Veteriner Fakultas Kedokteran Hewan, Institut Pertanian Bogor \\ *Penulis untuk korespondensi: rizalekokurniawan@gmail.com \\ Diterima 15 Januari 2021, Disetujui 23 Mei 2021
}

\begin{abstract}
ABSTRAK
Sarang burung walet (SBW) merupakan produk pangan asal hewan yang banyak dimanfaatkan dalam bidang kesehatan. Produk SBW telah diekspor ke berbagai negara, salah satunya adalah Tiongkok. Pangan yang diekspor ke Tiongkok berpotensi membawa bahaya pangan yang berisiko menggangu kesehatan manusia. Oleh karena itu, setiap produk dan pangan asal hewan harus memiliki jaminan keamanan pangan. Ulasan ini bertujuan untuk membahas tentang HACCP dalam menjamin keamanan pangan asal hewan khususnya sarang burung walet sebagai persyaratan ekspor sarang burung walet ke Tiongkok. Hazard Analysis Critical Control Point (HACCP) merupakan sistem keamanan pangan yang dikembangkan secara global untuk mengidentifikasi, mengevaluasi, dan mengendalikan bahaya - bahaya fisik, kimiawi, dan biologi sebagai syarat mengekspor produk SBW ke Tiongkok. Perusahaan yang telah memiliki HACCP diharapkan memiliki sistem untuk mencegah, atau mengurangi bahaya sampai taraf yang dapat diterima selama proses produksi. Titik kritis penerapan HACCP untuk memenuhi persyaratan ekspor ke Tiongkok berupa bebas dari Avian influenza, tidak melebihi batas bahaya fisik, kimia, dan biologi. Sistem keamanan pangan HACCP membantu mengidentifikasi, mencegah dan mengurangi bahaya hingga taraf yang dapat diterima melalui penetapan titik kendali kritis dan batas kritis produk SBW sehingga mampu menembus pasar ekspor Tiongkok.
\end{abstract}

Kata kunci: ekspor, HACCP, keamanan pangan, sarang burung walet, Tiongkok

\begin{abstract}
Edible Bird Nest (EBN) is a food product of animal origin that is widely used in human health. EBN products have been exported to various countries, such as China. EBN products exported to China have food concerns matter that risk disrupting human health. Therefore, every product and food of animal origin must have food safety guarantees. This review aims to discuss HACCP in ensuring food safety animal origin especially EBN as a requirement to export to China. Hazard Analysis Critical Control Point (HACCP) is a food safety system developed globally to identify, evaluate, and control physical, chemical, and biological hazards to fulfill the requirement of exporting SBW products to China. Companies that already have HACCP are expected to have systems to prevent or reduce hazards to an acceptable level during the production process. The critical control points of HACCP implementation is to ensure that SBW products meet export requirements to China free from Avian influenza, not exceeding the limits of physical, chemical, and biological hazards. HACCP's food safety system helps identify hazards and prevent or reduce hazards to an acceptable extent through the establishment of critical control points and critical limits of SBW products to expand China's export markets.
\end{abstract}

Keywords: export, HACCP, food safety, edible bird nest, China 


\section{PENDAHULUAN}

Sarang burung walet (SBW) merupakan salah satu produk pangan asal hewan komoditas ekspor Indonesia yang bernilai jual tinggi dan kaya nutrisi. Sarang tersebut terbuat dari air liur yang dihasilkan kelenjar sublingualis burung walet spesies Aerodramus fuciphaga (Teh \& Ma, 2018). Walet spesies Aerodramus fuciphaga yang di Kalimantan memiliki empat subspesies yaitu Aerodramus fuciphagus vestitus, A. fuciphagus germani, A. fuciphagus perplexus, dan A. fuciphagus fuciphagus (Fujita \& Leh, 2020). Spesies walet lain yang menghasilkan sarang burung, yaitu walet hitam (A. maximus), dan walet linchi (A. esculenta) (Connoly, 2016; Susilo, 2015). Sarang burung walet dihasilkan oleh walet betina yang digunakan untuk meletakkan telur, dan umumnya dibuat pada langit-langit gua atau rumah walet (Babji et al., 2015). Sarang-sarang walet yang ditemukan umumnya berbentuk setengah mangkok, serat panjang (stripe), dan remahan. Warna SBW juga beragam mulai dari warna putih, kuning, atau merah disertai serat rumput maupun bulu hitam (Hao \& Rahman, 2016) (Gambar 1).

Secara alamiah SBW rata rata walet membutuhkan waktu 30 hari untuk membangun sarang dengan laju pertumbuhan sarang pada dua minggu pertama secara berangsur menurun menurun pada minggu ke tiga dan keempat saat memasuki fase bertelur (Ramji et al., 2013).

Pemanfaatan SBW banyak digunakan sebagai tambahan produk pangan (Babji, 2014), bahan utama produk nutrisetikal seperti suplemen kesehatan, dan produk kecantikan (Daud et al., 2019). Sarang burung walet merupakan bahan pangan yang kaya protein, karbohidrat serta nutrisi lain seperti glikoprotein dengan 8 asam amino esensial diantaranya fenilalanin, valin, thronin, tryptophan, isoleusin, methionin, lysin, dan leusin (Quek et al., 2018; Daud et al., 2019). Bahan bahan lain yang juga terdapat pada sarang burung walet antara lain dari lemak (0.14-1.28\%), karbohidrat (25.62$31.40 \%$ ), dan protein (60-66\%) (Saengkrajang et al., 2013; Zainab et al., 2013).

Manfaat lain dari sarang burung walet diantaranya sebagai antioksidan (Teh \& Ma, 2018), meningkatkan proliferasi sel (Roh et al., 2012), memiliki efek anti-inflamasi (Rashed \& Nazaimoon, 2010), memperkuat tulang (Matsukawa et al., 2011), meningkatkan jumlah aktivasi sel $B$ sehingga meningkatkan kekebalan tubuh (Zhao et al., 2016), efek neuroprotektif (Yew et al., 2014), dan mencegah osteoarthritis (Chua et al., 2013).

Indonesia saat ini telah berhasil mengekspor SBW ke berbagai negara. Indonesia sendiri merupakan penghasil SBW terbesar di dunia dengan produksi mencapai $79.55 \%$ total produksi di dunia (Kementan, 2018). SBW Indonesia telah dijual ke 12 negara diantaranya China, Hongkong, Vietnam, Singapura, Amerika Serikat, Kanada, Thailand, Australia, Malaysia, Jepang, Laos, dan Korea Selatan (Kementan, 2020a). Salah satu negara tujuan terpenting untuk ekspor SBW Indonesia adalah Tiongkok. Harga dan kualitas SBW tergantung pada bentuk, warna dan asal geografis, harga SBW asal Indonesia bahkan bisa mencapai 7638 Dolar AS (Hao \& Rahman, 2016; Ito et al., 2020). Menurut Jory \& Saengthong (2007) total nilai perdagangan SBW di Tiongkok mencapai 4.2 juta Dolar AS pertahun. Menurut BPS (2020) ekspor SBW resmi ke Tiongkok terus meningkat, pada tahun 2015 hanya 18.4 ton, sampai puncaknya pada tahun 2019 mencapai 129.1 ton dengan nilai 219 juta dollar AS disajikan pada Gambar 2 (BPS, 2020).
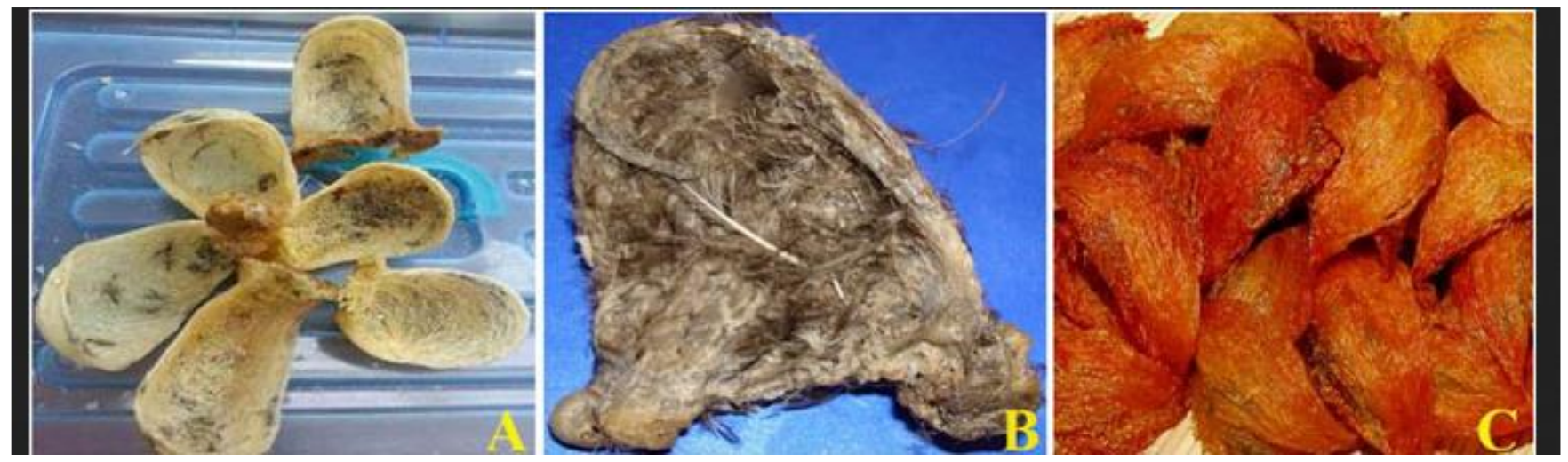

Gambar 1 Jenis warna SBW A. Putih B. Hitam disertai rumput. C. Merah (Lee et al., 2021) 


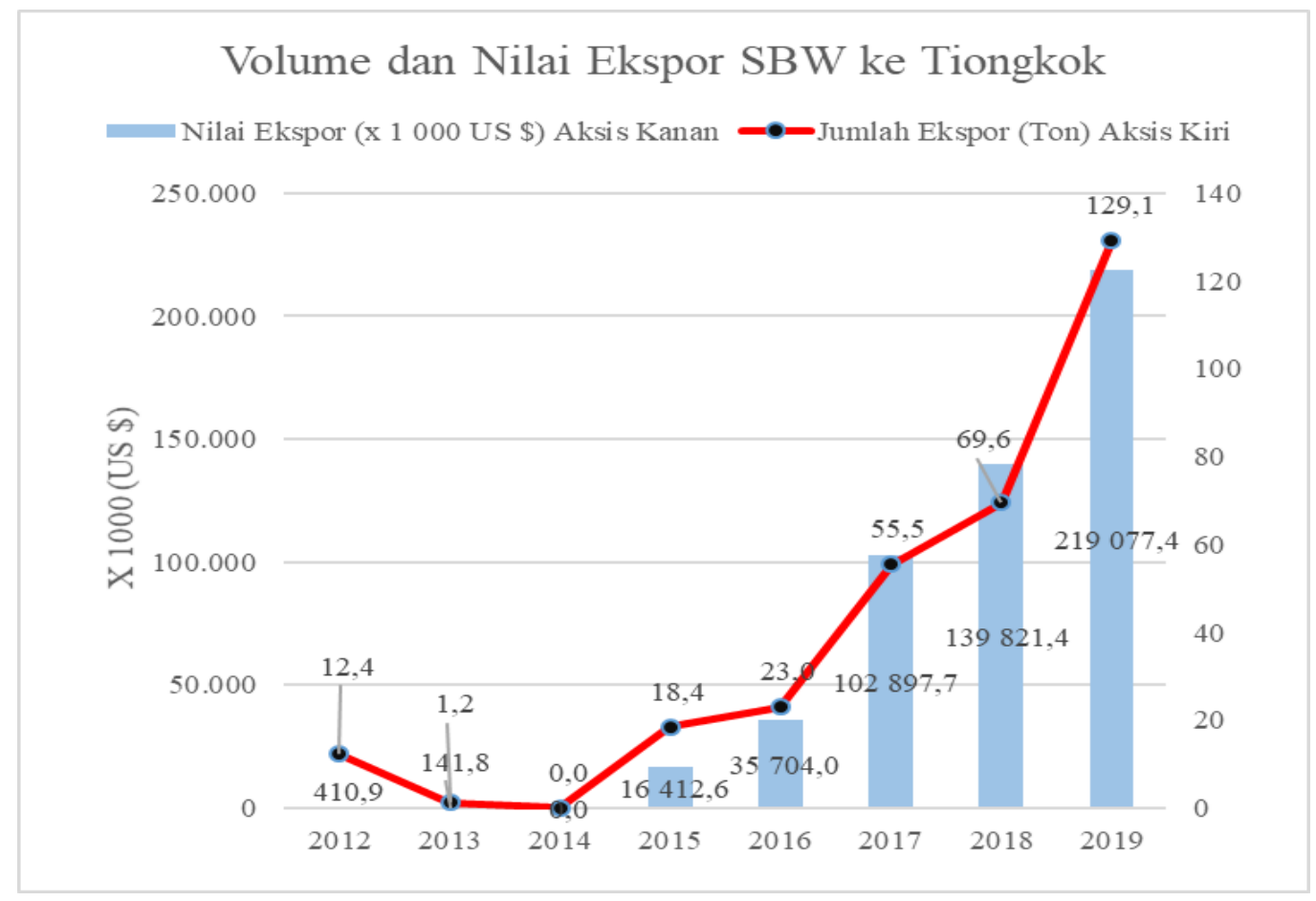

Gambar 2 Volume dan Nilai Ekspor SBW ke Tiongkok (BPS, 2020)

\section{BAHAN DAN METODE}

Metode penulisan ulasan menggunakan metode penelitian kualitatif deskriptif melalui pendekatan Analisis Data Sekunder (ADS). Data diperoleh melalui kajian literatur yang membahas persyaratan keamanan pangan terkait ekspor SBW ke Tiongkok. Kajian literatur bertujuan untuk mempelajari teori yang berhubungan dengan pembahasan topik penulisan pada selang waktu 2010-2020. Penulisan ulasan disusun dalam bentuk deskriptif berdasarkan sub topik bahasan menggunakan berbagai sumber melalui artikel, buku, jurnal dan sumber lain yang relevan terhadap tema yang ditulis serta memberikan kesimpulan dan evaluasi kritis (Ramdhani et al., 2014).

\section{PEMBAHASAN}

\section{Masalah Keamanan Pangan terkait Sarang Bu- rung Walet}

Bahaya atau Hazard yang berkaitan dengan keamanan pangan asal hewan khususnya SBW dapat terjadi pada setiap mata rantai, mulai dari produksi di rumah walet, unit pemrosesan, sampai produk tersebut didistribusikan dan disajikan kepada konsumen. Bahaya tersebut meliputi; bahaya fisik, bahaya biologis, dan bahaya kimiawi yang dapat mengakibatkan penyakit tular pangan (foodborne disease).

\section{Bahaya Fisik}

Saat SBW dipanen terdapat risiko pangan berupa bahaya fisik yaitu bulu burung, cangkang telur, serpihan kayu, dan rumput (Kew et al., 2014). Bahaya fisik pada makanan umumnya tidak menimbulkan penyakit atau keracunan namun merupakan indikator rendahnya sanitasi dan higiene, serta memberi persepsi buruk bagi pangan yang disajikan (Handayani, 2012). Komoditas SBW siap ekspor diwajibkan bebas serpihan kayu, bulu, atau benda asing lain secara visual (Barantan, 2014).

\section{Bahaya Biologis}

Menurut Wong et al., (2018) terdapat juga bahaya biologi sepertiBacillus, Staphylococcus aureus pada SBW yang belum diolah dan ditemukan pada sarang burung walet yang dijual komersial yang berasal dari Malaysia dan Indonesia pada produk yang sudah dipasteurisasi. Leong et al., (2019) melaporkan adanya bahaya biologi yang berisiko mengganggu kesehatan manusia yang disebabkan oleh bakteri Gram positif pada rumah burung walet seperti Bacillus, Lysinibacillus, Paenibacillus dan Sporosarcina. Sien et al., (2014) melaporkan terdapat Eschericia coli, dan Kew et al., (2014) melaporkan ditemukan fungi pada SBW. Menurut (Sien et al., 2014), cemaran biologis SBW yang 
ditemukan merupakan kontaminasi akibat lingkungan rumah walet atau habitat SBW tersebut diperoleh.

Staphylococcus dan Bacillus merupakan bakteri yang umum ditemukan pada sarang burung walet dan dapat menimbulkan masalah kesehatan manusia diantaranya terdapat dua jenis Bacillus yang ditemukan pada sarang burung walet yaitu Bacillus cereus dan Bacillus subtilis (Wong et al., 2018). Keduanya mampu menghasilkan endospora yang tahan panas sehingga tidak mati saat dipanaskan. Bakteri ini juga mampu mengeluarkan endotoksin yang menyebabkan muntah, kram perut, dan diare dengan masa inkubasi 1-16 jam (Jeßberger et al., 2015). Bacillus cereus dapat menyebabkan infeksi lain seperti konjungtivitis, keratitis, abses orbital maupun infeksi sekunder pada penderita dengan gangguan sistem imun. Sedangkan B. subtilis merupakan bakteri yang tahan dengan panas, zat kimia, maupun radiasi ultraviolet. Bakteri ini umum ditemukan pada tanah, air, dan tanaman yang mampu menyebabkan gangguan pernapasan dan alergi namun jarang menyebabkan intoksikasi makanan (Kimouli et al., 2012; Cote et al., 2015).

Staphylococcus yang ditemukan pada SBW diduga berasal dari kualitas higiene personal pekerja. Adapun spesises $S$. aureus yang lazim mencemari makanan mampu menghasilkan enterotoksin. Enterotoksin ini bersifat toksik bagi manusia dan hewan sangat tahan terhadap pemanasan, meskipun bakteritelah mati karena pemanasan (pemanasan pada suhu $66^{\circ} \mathrm{C}$ selama 10 menit) namun, toksinnya masih dapat bertahan pada suhu $100{ }^{\circ} \mathrm{C}$ selama 30 menit (Saimah, 2015). Higiene dan sanitasi dalam mengelola bahan makanan merupakan upaya untuk mengendalikan faktor risiko terjadinya kontaminasi, baik yang berasal dari bahan makanan, orang, tempat, dan peralatan agar aman dikonsumsi (Handayani, 2012).

\section{Bahaya Kimiawi}

Bahaya pangan pada SBW lainnya yang sering ditemukan yaitu adanya bahaya kimiawi kadar nitrit (Yusuf et al., 2020) dan kandungan logam berat (Ma et al., 2020). Salah satu bahaya kimiawi yang mendapatkan perhatian utama pada SBW yang diekspor ke Tiongkok adalah kadar nitrit. Indonesia menetapkan kadar nitrit 125 ppm pada SBW melalui Permentan 41 tahun 2013 (Permentan, 2013) sedangkan untuk tujuan ekspor, pemerintah Tiongkok menetapkan batas kadar nitrit $30 \mathrm{ppm}$. Kandungan nitrit dalam darah di atas $65 \%$ dapat menyebabkan methemoglobinemia dan berakibat kematian. Kandungan nitrit dapat membentuk senyawa nitrosamin yang bersifat karsinogenik pada saluran pencernaan (Chan et al., 2013).

Secara kimiawi istilah logam berat mengacu pada metalloid yang memiliki nomor massa atom lebih besar dari 20 seperti kadmium (Cd), merkuri ( $\mathrm{Hg})$, arsen (As), timbal $(\mathrm{Pb})$, kromium, $(\mathrm{Cr})$, nikel $(\mathrm{Ni})$, dan seng (Zn) (Rascio \& Navarizzo, 2011). Pemerintah Indonesia telah menerapkan batas maksimum logam berat pada pangan yang diatur dalam BSN (1998) diantaranya adalah arsen (As) $0.25 \mathrm{mg} / \mathrm{kg}$, kadmium (Cd) $0.2 \mathrm{mg} / \mathrm{kg}$, merkuri ( $\mathrm{Hg}$ ) $0.03 \mathrm{mg} / \mathrm{kg}$, timbal (Pb) $0.25 \mathrm{mg} / \mathrm{kg}$ dan timah (Sn) $250 \mathrm{mg} / \mathrm{kg}$. Standar batas cemaran secara khusus pada produk SBW ekspor belum pernah dilaporkan baik produk jadi maupun produk mentah. Akumulasi logam berat bersifat racun pada tubuh dan dapat menyebabkan gangguan kesehatan seperti kanker (Gosh \& Indra, 2018), gangguan syaraf (Kankia \& Abdulhamid, 2014) gangguan psikis (Yorifuji et al., 2011), bahkan kematian (Ha et al. 2016). Cemaran logam berat pada SBW diduga dipengaruhi oleh lokasi sumber pakan yang tercemar di sekitar habitat walet baik yang berasal dari gua maupun dari dari dalam rumah walet. Hal ini disebabkan walet merupakan insektivora yang menggantungkan kelimpahan pakan pada kondisi ekosistemnya (Fujita \& Leh, 2020; Chen et al., 2014). Cemaran logam berat menjadi isu lingkungan yang penting karena dapat mempengaruhi keamanan pangan hasil produksi sektor pertanian (Hu et al., 2017).

Potensi - potensi bahaya fisik, biologis maupun kimiawi pada SBW perlu dikendalikan agar tidak menyebabkan masalah kesehatan bagi konsumen. Negara menjamin bahwa setiap konsumen yang membeli barang terutama makanan berhak mendapatkan kenyamanan, keamanan, dan keselamatan dalam mengonsumsi barang dan jasa. Sehingga diperlukan adanya jaminan keamanan pangan asal hewan terutama pada sarang burung wallet.

Hazard Analysis Critical Control Point (HACCP) sebagai Syarat Jaminan Keamanan Produk Sarang Burung Walet

Konsep dasar HACCP pertama kali dikembangkan pada tahun 1959 namun baru diterapkan secara luas di AS tahun 1971 oleh perusahaan Pillsbury yang 
bekerja sama dengan The National Aeronautics and Space (NASA), the Natick Laboratories of the US Army dan (Mortimore \& Wallace, 2013). Sistem HACCP yang pertama kali dipublikasikan pada tahun 1971 oleh perusahaan makanan Pillsbury di Conference on Food Protection (CFP) memiliki tiga prinsip utama yaitu: identifikasi dan penilaian bahaya yang berasosiasi dengan pangan dari awal hingga akhir produksi, penentuan titik kendali kritis untuk mengendalikan bahaya pangan yang berisiko kesehatan selama pemrosesan pangan, dan menjamin sistem pemantuan untuk memantau titik kendali kritis (Ibrahim, 2020). The National Advisory Committee of Microbiological Criteria for Foods (NACMCF) pada tahun 1993 merevisi pedoman dan standar HACCP menjadi lima langkah awal untuk pengembangan dan tujuh prinsip sistem HACCP (NACMCF, 1998). Saat ini, HACCP adalah sistem jaminan keamanan pangan yang diakui secara internasional untuk mengurangi risiko bahaya untuk produksi pangan domestik dan internasional (FDA, 2004). Standar HACCP yang diterapkan di Indonesia diadopsi dan diterjemahkan dari Codex Committee on Food Hygiene yang mulai dikenalkan pada oktober tahun 1991 (BSN, 1998).

Sistem HACCP merupakan manajemen yang bersifat sistematis untuk mengidentifikasi, mengevaluasi, dan mengendalikan bahaya - bahaya keamanan pangan (Mortimore \& Wallace, 2013). Berdasarkan National Advisory Committee on Microbiological Criteria for Foods (NACMCF) tentang HACCP terdapat lima langkah awal persiapan dan tujuh prinsip HACCP. Lima langkah awal tersebut meliputi pembentukan tim HACCP, pendeskripsian produk, identifikasi tujuan penggunaan produk, pembuatan diagram alir, dan verifikasi diagram alir. Tujuh prinsip dasar lainnya yaitu analisa bahaya, menentukan titik kendali kritis (CCP), menetapkan batas kritis, menetapkan sistem untuk memantau pengendalian titik kendali kritis, menetapkan tindakan perbaikan, menetapkan prosedur verifikasi untuk memastikan bahwa sistem HACCP bekerja secara efektif, dan menetapkan dokumentasi seluruh proses produksi. Sehingga dengan HACCP yang efektif setiap produk yang dihasilkan terjamin keamanan pangannya (Mortimore \& Wallace, 2013).

Keamanan pangan merupakan persyaratan utama yang semakin penting di era perdagangan bebas. Pangan yang aman, bermutu, bergizi, dan tersedia cukup merupakan prasyarat utama yang harus dipenuhi dalam upaya terselenggaranya suatu sistem pangan yang memberikan perlindungan bagi konsumen. Pangan asal hewan seperti daging, susu dan telur serta hasil olahannya umumnya bersifat mudah rusak (perishable) dan memiliki potensi mengandung bahaya biologik, kimiawi dan atau fisik, yang dikenal sebagai potentially hazardous foods (PHF) (IFT, 2013). Produk asal hewan lain seperti SBW, merupakan produk memiliki karakter rapuh dan berpotensi mengandung nitrit tinggi yang berbahaya bagi kesehatan sehingga Tiongkok membatasi kadar nitrit produk SBW yang masuk ke negaranya 30 ppm (Dai et al., 2020). Selain itu, pangan asal hewan juga berpotensi membawa agen penyakit hewan (bakteri, cacing, protozoa, prion) dan bahaya asing lain yang dapat membahayakan kesehatan manusia (Kusumaningsih, 2012). Oleh sebab itu, penanganan produk tersebut harus higienis. Penerapan HACCP juga dinilai mampu menjamin keamanan pangan asal hewan. HACCP secara luas telah diterapkan untuk mengatasi masalah pangan produk asal hewan antara lain pada daging (Wicaksani \& Adriyani, 2018; Tomasevic et al., 2013), produksi telur (Nam et al., 2014), susu (Lievaart et al., 2011), madu (Handschuch et al., 2012), dan keju (Uyttendaele et al., 2016).

Tiongkok mewajibkan setiap unit usaha yang mengekspor produk SBW telah memenuhi ketentuan pemeriksaan, karantina, dan keamanan pangan. Pemerintah Indonesia berperan menetapkan peraturan, prosedur administrasi, standar program pemeriksaan, dan karantina untuk ekspor produk SBW ke Tiongkok. Persyaratan unit usaha yang harus dipenuhi untuk mendapatkan sertifikat sanitasi yaitu tempat pemrosesan SBW telah disertifikasi sistem HACCP dan memenuhi tatacara pemrosesan sarang walet yang baik dan ditetapkan sebagai instalasi karantina produk hewan (IKPH) (Barantan, 2013). Penerapan sistem HACCP telah mencakup persyaratan yang dicantumkan dalam protokol kerjasama kedua negara seperti deskripsi produk berupa nama, berat produk, nomor registrasi, dan ketelusuran. Selain itu, kecukupan persyaratan higiene dan sanitasi unit pemrosesan SBW ditandai dengan unit usaha telah mendapatkan Nomor Kontrol Veteriner (NKV).

Upaya penerapan HACCP dan sertifikat NKV merupakan sistem yang saling terkait. Sertifikat NKV merupakan bukti tertulis yang sah telah dipenuhinya persyaratan higiene sanitasi sebagai kelayakan dasar jaminan keamanan pangan asal hewan pada unit usaha pangan asal hewan khususnya produk SBW (Permentan, 2013). Sistem HACCP dapat diterapkan secara efektif jika memenuhi program persyaratan kelayakan dasar yang terdiri dari cara produksi pangan yang baik (CPPB) dan standar prosedur operasional sanitasi. Sertifikat NKV dapat digunakan 
sebagai persyarat kelayaan dasar unit usaha produk hewan sebagai bagian penerapan HACCP.

Perkembangan penerapan HACCP di industri walet di Indonesia saat ini terus berkembang, tercatat 47 perusahaan SBW telah memiliki sertifikat HACCP namun baru 23 perusahaan yang telah mendapatkan sertifikasi HACCP dan nomor registrasi sebagai eksportir ke Tiongkok sedangkan 24 perusahaan lainnya menunggu hasil audit Badan Bea Cukai Tiongkok General Administration of Customs of the People's Republic of China (GACC) (Siregar, 2020). Saat ini terdapat 59 perusahaan luar negeri yang terdaftar sebagai eksportir SBW ke Tongkok terdiri dari 34 perusahaan asal Malaysia, 23 perusahaan asal Indonesia dan 2 perusahaan asal Thailand (CAIQ, 2020). Penerapan HACCP pada produk asal hewan khususnya eksportir sarang burung walet di Indonesia masih berpeluang untuk terus meningkat. Penerapan HACCP pada produk SBW berbeda dengan bahan pangan asal hewan lain, karena sebagian besar tahap pemrosesan SBW bersifat tradisional sehingga berisiko terkontaminasi dari pekerja. Salah satu proses pembersihan SBW seperti pencabutan bulu, membutuhkan ketelitian tinggi (Akhsani, 2021). Sarang burung walet setidaknya diproduksi melalui beberapa tahap diantaranya adalah pemanenan, pembersihan sarang (pencabutaan bulu dan kotoran dari sarang), pengeringan, pembentukan ulang, penyimpanan, dan pengemasan (Jong et al., 2013).

Kajian HACCP pada unit usaha sarang burung walet di Indonesia masih sangat terbatas. Perkembangan penelitian HACCP di bidang industri SBW belum pernah dilakukan di Indonesia. Kebutuhan implementasi HACCP pada industri SBW mutlak diperlukan, terutama pada unit usaha yang berorientasi ekspor telah disertifikasi HACCP sehingga nantinya akan lebih banyak kajian tentang HACCP di industri SBW. Produk SBW yang akan diekspor ke Tiongkok harus memenuhi protokol pemerintah tentang persyaratan higienis karantina dan pemeriksaan produk sesuai dengan keputusan Badan Karantina Pertanian Kementerian Pertanian Republik Indonesia (Barantan, 2013).

\section{Peluang dan Tantangan Pengembangan Penera- pan HACCP Industri SBW di Indonesia}

Indonesia telah mencanangkan program GRATIEKS (Gerakan Tiga Kali Ekspor). Gratieks merupakan gerakan peningkatan ekspor pertanian yang digagas Menteri Pertanian melalui kerjasama berbagai pemegang kepentingan pembangunan pertanian dari hulu sampai hilir untuk mendorong jumlah dan nilai ekspor komoditas pertanian termasuk salah satunya adalah produk SBW. Program tersebut berpeluang mendorong bertambahnya para eksportir SBW tujuan Tiongkok. Saat ini SBW asal Indonesia di Tiongkok masih berjumlah $10.25 \%$ dari total ekspor SBW ke luar negeri (BPS, 2020). Hal ini masih berpeluang untuk mendorong eksportir mengutamakan penjualan SBW ke Tiongkok. Faktor lain yang juga dapat mendorong eksportir untuk meningkatkan jumlah ekspor SBW ke Tiongkok adalah harga jual SBW di Tiongkok lebih tinggi dibandingkan negara lain (Lee et al., 2017). Sertifikat HACCP merupakan persyaratan utama menjadi eksportir terdaftar di Tiongkok. Hal tersebut menjadi perhatian pemerintah Tiongkok untuk menjamin produk SBW yang masuk ke negaranya bersih, aman, resmi, dan legal. Menurut Shukri et al. (2018) harga jual SBW bersih sesuai standar HACCP yang dijual oleh eksportir resmi bernilai lebih tinggi, dan kualitas yang lebih baik.

Terbukanya peluang pasar yang sangat besar sejalan dengan pertumbuhan unit usaha dan rumahrumah walet baru maupun SBW asal goa yang tersebar di 18 provinsi merupakan faktor melimpahnya SBW (Kementan, 2020b). Hal ini perlu dimanfaatkan dengan baik agar tetap menghasilkan SBW secara berkelanjutan. Selain itu, peran pemerintah perlu mengawasi para unit usaha untuk tetap menjamin berjalannya sistem jaminan keamanan pangan melalui HACCP. Diharapkan kedepan produk SBW asal Indonesia dapat dipastikan aman dari bahaya pangan yang memenuhi persyaratan higiene sanitasi dan mampu menembus pasar ekspor Tiongkok secara langsung karena Tiongkok melalui GACC mewajibkan sertifikasi HACCP bagi para pengusaha SBW.

Selain itu, pengusaha SBW menghadapi tantangan ancaman resesi akibat pandemi COVID-19 namun mampu dihadapi sehingga masih tetap tumbuh. Direktorat Jenderal Peternakan dan Kesehatan Hewan Kementerian Pertanian Republik Indonesia melaporkan ekspor SBW pada triwulan pertama masih menunjukkan pertumbuhan rata-rata $25,35 \%$ /bulan (Kementan, 2020a).

Proses SBW siap ekspor yang memerlukan ketekunaan dan masih bersifat tradisional diduga oleh otoritas Tiongkok menjadi motif penggunaan bahan pangan berbahaya atau menggunakan proses tambahan yang menyalahi etika bisnis. Terdapat enam cara ilegal yang lazim ditemukan pada produk SBW yaitu penggunaan bahan kimia untuk menghilangkan bulu dengan tujuan mengurangi biaya pekerja, penambahan zat pemutih menggunakan 
hidrogen peroksida, sulfur dioksida atau sulfur trioksida, menyemprotkan air untuk meningkatkan berat produk, menambahkan pengawet, bahan pewarna merah tambahan, dan pemalsuan (Dai et al., 2020). Hal ini menyebabkan pemerintah Tiongkok selektif untuk mengeluarkan izin bagi para pengusaha eksportir SBW. Kondisi ini memaksa para eksportir untuk meningkatkan standar keamanan pangan SBW yang diekspor ke Tiongkok.

Walaupun berbagai permasalahan dan tantangan yang dihadapi para pengusaha di industri SBW Indonesia, namun beberapa peluang dapat dimanfaatkan. Saat ini pemerintah mendorong kerjasama bilateral antara Indonesia dan Tiongkok melalui GACC untuk percepatan izin ekspor bagi unit usaha yang telah memenuhi persyaratan keamanan pangan sehingga mampu menjual produk SBW secara langsung ke Tiongkok.

"Penulis menyatakan tidak ada konflik kepentingan dengan pihak-pihak yang terkait dalam penelitian ini".

\section{DAFTAR PUSTAKA}

Akhsani OR. 2021. Faktor Risiko Kelelahan Mata Tenaga Kerja Sarang Burung Walet Di Kecamatan Mantup, Lamongan. Jurnal Kesehatan 14(1): 28-35.

Babji AS. 2014. Review: development of downstream products from Edible Bird's Nest. Edible Bird's Nest Industry Conference. Putrajaya Malaysia.

Babji AS, Nurfatin MH, Syarmila IKE, Masitah $M$. 2015. Secrets of Edible Bird's Nest. UTAR Journal Agricultural Science 1(1): 32-37.

[Barantan] Badan Karantina Pertanian. 2013. Keputusan Kepala Badan Karantina Pertanian Nomor 832/Kpts/OT.140/L/3/2013 tentang Pedoman persyaratan dan tindakan karantina hewan terhadap pengeluaran sarang burung walet dari wilayah Negara Republik Indonesia ke Republik Rakyat China. Badan Karantina Pertanian. Jakarta.

[Barantan] Badan Karantina Pertanian. 2014. Keputusan Kepala Badan Karantina Pertanian Nomor 416/Kpts/OT.160/L/4/2014 tentang Pedoman Pemeriksaan Kandungan Nitrit Sarang Walet untuk Pengeluaran ke Negara Republik Rakyat China. Badan Karantina Pertanian. Jakarta.

[BSN] Badan Standardisasi Nasional. 1998. Tentang Sistem Analisa Bahaya dan Pengendalian Titik Kritis Serta Pedoman Penerapannya SNI No 01 4852. BSN. Jakarta.
[BPS] Badan Pusat Statistik. 2020. Ekspor Sarang Burung dengan Tujuan Negara Utama 2012-2019. https://www.bps.go.id/statictable/2019/02/25/202 2/ekspor-sarang-burung-menurut-negara-tujuanutama-2012-2019.html. Download: July 1, 2010.

Chan GKL, Zhu KY, Chou DJY, Guo AJY, Dong TTX, Tsim KWK. 2013. Surveillance of nitrite level in cubilose: evaluation of removal method and proposed origin of contamination. Food Control 34: 637-644.

Chen JXJ, Lim PKC, Wong SF, Mak JW. 2014. Determination of the presence and level of heavy metals and other elements in raw and commercial Edible Bird nests. The Malaysian Journal of Nutrition 20(3): 377-391.

Chua KH, Lee TH, Nagandran K, Yahaya NHM, Lee CT, Tjih ET. 2013. Edible Bird's nest extract as a chondro-protective agent for human chondrocytes isolated from osteoarthritic knee: in vitro study. BMC Complete Alternative Medicine 13(1): 1-9. DOI: 10.1186/1472-6882-13-19

Connoly C. 2016. A Landscape Political Ecology of 'Swiftlet Farming' in Malaysian Cities. Disertasi S3. Graduate School, University of Manchester. Manchester.

Cote CK, Heffron JD, Bozue JA, Welkos SL, 2015. Chapter 102 - Bacillus anthracis and other Bacillus species. In Molecular Medical Microbiology $2^{\text {nd }}$ ed. Academy Press Elsevier. United Kingdom. p1789-1844.

Dai Y, Cao J, Wang Y, Chen Y, Jiang L. 2020. A comprehensive review of Edible Bird's nest. Journal Food Research International 109875. DOI:10.1016/j.foodres.2020.109875.

Daud NA, Yusop SM, Babji AS, Lim SJ, Sarbini SR, Yan TH. 2019. Edible Bird's Nest : physicochemical properties, production, and application of bioactive extracts and glycopeptides Edible Bird's nest: physicochemical properties, production, and. Food Review International 37(2): 177-196. DOI:10.1080/87559129.2019.1696359.

[FDA] Food and Drug Administration. 2004. HACCP Guidelines. Department of Health and Human services Public Health Service. United States.

Fujita M, Leh C. 2020. The feeding ecology of Ediblenest swiftlets in a modified landscape in Sarawak. In Anthropogenic Tropical Forests. Springer. Singapore. p401-415.

Gosh K, Indra N. 2018. Cadmium treatment induces echinocytosis, DNA damage, inflam-mation, and apoptosis in cardiac tissue of albino Wistar rats. Environment Toxicology Pharmacoly 59: 43-52. DOI:10.1016/j.etap.2018.02.009. 
Handayani T. 2012. Kajian Sistem Keamanan Pangan Untuk Industri Jasa Boga, Studi Kasus Pada PT ELN. Tesis S2. Sekolah Pascasarjana, Institut Pertanian Bogor. Bogor.

Handschuch C, Wollni M, Corrêa Neto AM. 2012. Knowledge and implementation of HACCP-based management systems among small-scale honey producers in Brazil. Journal Chain Network Science 12(1): 55-66. DOI:10.3920/JCNS2012.x003.

Ha E, Basu N, Bose-O'Reilly S, Dórea JG., Mcsorley E., Sakamoto M, Chan HM. 2016. Current Progress on Understanding the Impact of Mercury on Human Health. Environmental Research 68(1): 167-182.

Hao Q, Rahman A. 2016. Swiftlets and Edible Bird's nest industry in Asia. Journal Pertanika 2(1): 32-48.

Hu BF, Chen S C, Hu J, Xia F, Xu JF, Li Y, Shi Z. 2017. Application of portable XRFand VNIR sensors for rapid assessment of soil heavy metal pollution. PLoS ONE. 12(2). DOI:10.1371/journal .pone. 0172438 .

Ibrahim OO. 2020. Introduction to Hazard Analysis Critical Control Points (HACCP). EC Microbiology 16(3): 1-7.

[IFT] The Institute food and Technology. 2013. Evaluation and definition of potentially hazardous foods. Journal America Medicine Association 2: 1290-1291.

Ito $\mathrm{Y}$, Matsumoto, Usup A, Fukui, Yamamoto Y. 2020. Edible bird's nest: A way for sustainable agriculture livelihood in Indonesia. https://papers .ssrn.com/sol3/papers.cfm?abstract_id=3531323. Download: November 29, 2020.

Jong CH, Tay KM, Lim CP. 2013. Application of the fuzzy failure mode and effect analysis methodology to edible bird nest processing. Computers and Electronics in Agriculture 96: 90-108.

Jory P, Saengthong J. 2007. Birds' Nests: secrets of a billion-dollar business. Thailand Research Fund, Regional Studies Program, Walailak University.

Jeßberger N, Krey VM, Rademacher C, Böhm ME, Mohr AK, Ehling-Schulz M, Scherer S, Märtlbauer E. 2015. From genome to toxicity: a combinatory approach highlights the complexity of enterotoxin production in Bacillus cereus. Frontiers in Microbiology 6: 560 . DOI: $10.3389 / \mathrm{fmi}$ cb.2015.00560.

Kankia HI, Abdulhamid Y. 2014. Determination of accumulated heavy metals in benthicinvertebrates found in Ajiwa Dam, Katsina State, Northern Nigeria. Archives of Applied Science Research 6: 80-87.
[Kemendag] 2019. Kementerian Perdagangan Republik Indonesia. Sarang Burung Walet Primadona Ekspor RI ke China. https://www.kemen dag.go.id/id/news/2019/07/29/sarang-burungwalet-primadona-ekspor-ri-ke-china. Download: November 29, 2020.

[Kementan]. 2018. Kementerian Pertanian Republik Indonesia. Dukung Ekspor, Kementan Paparkan Sistem Sertifikasi Karantina Dihadapan Ratusan Buyer Asal Tiongkok. https://www.pertanian. go.id/home/?show=news\&act=view\&id=3438.

Download: November 29, 2020.

[Kementan] 2020a. Kementerian Pertanian Republik Indonesia. Sertifikasi NKV Dorong Peningkatan Daya Saing Produk Sarang Burung Walet. https://ditjenpkh.pertanian.go.id/sertifikasi-nkvdorong-peningkatan-daya-saing-produk-sarangburung-walet. Download: November 29, 2020.

[Kementan] 2020b. Kementerian Pertanian Republik Indonesia. Januari Maret 2020, Ekspor Sarang Burung Walet Indonesia Capai Rp 1,578 Triliun. https://ditjenpkh.pertanian.go.id/januari-maret2020-ekspor-sarang-burung-walet-indonesia-capairp-1-578-triliun. Download: November 29, 2020.

Kew PE, Wong SF, Lim PKC. Mak JW. 2014. Structural analysis of raw and commercial farm edible bird nests. Tropical Biomedicine 31(1): 1-14.

Kimouli M, Vrioni G, Papadopoulou M, Koumaki V, Petropoulou D, Gounaris A, Friedrich AW, Tsakris A. 2012. Two cases of severe sepsis caused by Bacillus pumilus in neonatal infants. Journal of Medical Microbiology 61(4): 596-599.

Kusumaningsih A. 2012. Faktor Pemicu Kasus Foodborne Disease asal Ternak. http://bbalitvet. litbang.pertanian.go.id/ind/images/dokumen/Perpu stakaan/bibliografi/2018/1846.pdf. Download: Desember 1, 2020.

Lee TH, Wani WA, Koay YS, Kavita S, Tan ETT, Shreaz S. 2017. Recent advances in the identification and authentication methods of edible bird's nest. Food Research International 100: 14-27.

Lee $\mathrm{TH}$, Wani WA, Lee $\mathrm{CH}$, Cheng $\mathrm{KC}$, Shreaz $\mathrm{S}$, Wong S, Hamdan N, Azmi NA. 2021. Edible Bird's Nest: the functional values of the prized animalbased bioproduct from Southeast Asia review. Frontiers in Pharmacology 12: 626233.

Leong SS, Samuel L, Chia HC, Kueh JHR, Kwan YM. 2019. Biorisk assessment of antibiotic-resistant pathogenic bacteria isolated from swiftlet houses in Sarawak. Journal Pertanika Tropical Agricultural Science 42(1): 285-303. 
Lievaart JJ, Noordhuizen JPTM, Beek E Van, Beek C Van Der. 2011. The Hazard analysis critical control point's (HACCP) concept as applied to some chemical, physical and microbiological contaminants of milk on dairy farms. A prototype The Hazard Analysis Critical Control Point's (HACCP) concept as applied to so. 2176: 20-29. DOI:10.1080/01652176.2005.9695183.

Lutfi M, Argo BD, Hartini S. 2019. Identifikasi potensi bahaya dan pemantauan critical point (HACCP) produk makanan penerbangan. Pro Food 5(1): 448. DOI:10.29303/profood.v5i1.95.

Ma X, Zhang J, Liang J, Chen Y. 2020. Element analysis of house-and cave-ebn (Edible bird's nest) traceability by inductively coupled plasma-mass spectrometry (ICP-MS) integrated with chemometrics. Mater Express 10(7): 1141-1148. DOI:10.1166/mex.2020.1742.

Matsukawa N, Matsumoto M, Bukawa W, Chiji H, Nakayama K, Hara H. 2011. Improvement of bone strength and dermal thickness due to dietary edible bird's nest extract in ovariectomized rats. Bioscience Biotechnology Biochemistry 75(3): 590-592.

Mortimore S, Wallace C. 2013. HACCP A Practical Approach. Springer. London. DOI 10.1007/978-14614-5028-3

[NACMCF] National Advisory Committee on Microbiological Criteria for Foods. 1998. Hazard analysis and critical control point system and guidelines for its application. The Journal of Food Protection. 61: $762-775$.

Nam IS, Kim HS, Seo KM, Ahn JH. 2014. Analysis of productivity and strengths and weaknesses of the application of the HACCP system in laying hen farms 41(2):93-98.

[Permentan] Peraturan Menteri Pertanian. 2013. Tindakan Karantina Hewan Terhadap Pemasukan atau Pengeluaran Sarang Walet ke dan dari dalam Wilayah Negara Republik Indonesia. Nomor 41/Permentan/OT.140/3/2013. Kementerian Pertanian Republik Indonesia. Jakarta.

Quek MC, Chin NL, Yusof YA, Law CL, Tan SW. 2018. Characterization of edible bird's nest of different production, species and geographical origins using nutritional composition, physicochemical properties and antioxidant activities. Food Research International 109: 35-43.

Ramdhani A, Ramdhani MA, Amin AS. 2014. Writing a literature review research paper: a step-by-step approach. The Journal of Applied Behavioral Science 3 1: 47-56.
Ramji MFR, Koon LC, Rahman MA. 2013. Roosting and nest building behaviour of the Whitenest Swiflet Aerodramus fuchiphagus (Thunberg) (Aves: Apodidae) in farmed colonies. The Raffles Bulletin Zoology 29: 225-235.

Rascio N, Navariizzo F. 2011. Heavy metal hyperaccumulating plants: how and why do they do it, and what makes them so interesting. Plant Science. 18: 169-181. DOI:10.1016 /j.plantsci.2010.08.016.

Rashed AA, Nazaimoon WW. 2010. Effect of edible bird's nest on $\mathrm{CaCO}-2$ cell proliferation. The Journal of Food Science and Technology. 8(3): 126-130.

Roh KB, Lee J, Kim YS, Park J, Kim JH, Lee JL. 2012. Mechanisms of Edible Bird's Nest extractinduced proliferation of human adipose-derived stem cells. Evidence-Based Complementary and Alternative Medicine 11.

Saimah. 2015. Dekontaminasi Bakteri Escherichia coli dan Staphylococcus aureus pada Sarang Burung Walet dengan Perlakuan Pemanasan. Tesis S2. Sekolah Pascasarjana, Institut Pertanian Bogor. Bogor

Saengkrajang W, Matan N, Matan N. 2013. Nutritional composition of the farmed edible bird's nest (Collocalia fuciphaga) in Thailand. Journal Food Composition 31: 41-45.

Shukri NNHM, Nawi NM, Abdullah AM, Norsida MAN. 2018. Consumer's perception on the quality of controversial contents in Edible Bird's nest products. Journal Pertanika 4(1): 1-9.

Sien LS, Chuan CH, Lihan S, Yee LT. 2014. Isolation and identification of airborne bacteria inside swiftlet houses in Sarawak, Malaysia. Makara Journal of Science. 17(3). doi:10.7454/mss .v17i3.2950.

Siregar E. 2020. https://www.antaranews.com /berita/1828336/kemendag-23-eksportir-sarangwalet-ke-rrt-punya-sertifikat. Download: November 29, 2020.

Susilo H. 2015. Penuruan kadar nitrit dan perubahan kualitas akibat proses pencucian pada sarang burung walet. Tesis S2. Sekolah Pascasarjana, Institut Pertanian Bogor. Bogor

Teh SS, Ma ZF. 2018. Bioactive components and pharmacological properties of Edible Bird's nest. International Proceedings of Chemical, Biological, and Environment Engineering 103. DOI: 10.7763/IPCBEE 
Tomasevic I, Smigic N, Dekic I, Zaric V, Tomic N, Rajkovic A. 2013. Serbian meat industry: A survey on food safety management systems implementation. Food Control. DOI:10.1016/j.foodcont. 2012.11.046.

Uyttendaele M, De Boeck E, Jacxsens L. 2016. Challenges in food safety as part of food security: lessons learnt on food safety in a globalized world. Procedia Food Science 6:16-22. DOI:10.1016/j. profoo.2016.02.003.

Wicaksani AL, Adriyani R. 2018. Penerapan HACCP dalam proses produksi menu daging rendang di inflight catering. Media Gizi Indonesia 12(1): 88. DOI:10.20473/mgi.v12i1.88-97.

Wong SF, Lim PKC, Mak JW, Ooi SS, Chen DKF. 2018. Molecular characterization of culturable bacteria in raw and commercial edible bird nest (EBNs). International Food Research Journal 25(3): 966-974.

Yew MY, Koh RY, Chye SM, Othman I, Ng KY. 2014. Edible bird's nest ameliorates oxidative stressinduced apoptosis in $\mathrm{SH}_{-} \mathrm{SY}_{5} \mathrm{Y}$ human neuroblas toma cells. BMC Complement Alternative Medicine 14: 391.

Yorifuji T, Tsuda T, Inoue S, Takao S, Harada M. 2011. Long-term exposure to methylmercury and psychiatric symptoms in residents of Minamata, Japan. Environment International 37(5): 907-913.

Yusuf B, Farahmida P, Jamaluddin AW, Amir MN, Maulany RI, Sari DK. 2020. Preliminary study of nitrite content in South Sulawesi uncleaned edible bird nest. InIOP Conference Series: Earth and Environmental Science 486(1).

Zainab $\mathrm{H}$, Ibrahim $\mathrm{NH}$, Sarojini J, Kamaruddin $\mathrm{H}$, Othman H, Lee B. 2013. Nutritional properties of edible bird nest. Journal Asian Science Research 3(6): 600-607

Zhao R, Li G, Kong XJ, Huang XY, Li W, Zeng YY. 2016. The improvement effects of edible bird's nest on proliferation and activation of B lymphocyte and its antagonistic effects on immunosuppression induced by cyclophosphamide. Drug Design Development Therapy 10: 371-381. 